\title{
English-medium: Schooling, social mobility, and inequality in Bangalore, India
}

Dr Sazana Jayadeva

Institute of Asian Studies, GIGA German Institute of Global and Area

Studies, Hamburg, Germany

\section{To cite:}

Jayadeva, S. (2019), English-Medium: Schooling, Social Mobility, and Inequality in Bangalore, India. Anthropology \& Education Quarterly, 50: 151-169. doi: $\underline{10.1111 / \text { aeq.12287 }}$

\begin{abstract}
Focusing on low-cost English-medium schools, this article investigates whether the ideology of the transformative potential of English-medium education squares with most people's experiences of this education in urban India. It shows how such schools enable socioeconomic mobility among the middle classes, while also creating new forms of inequality. It argues that a meaningful evaluation of education outcomes requires understanding students' and their parents' experiences of an education system and its impact on their lives.
\end{abstract}

Keywords: English-medium schools, social mobility, post-liberalization India, education outcomes, Affordable Private Schools 


\section{Introduction}

The English language has long been an important marker of status in post-colonial India. However, since the liberalisation of the economy in the early 1990s, an unprecedentedly large section of the population has come to experience proficiency in the language as a potent marker of middle-class identity, a fine differentiator of status within and among the middle classes, and a crucial vehicle of socio-economic mobility. Particularly in India's metropolitan cities - but increasingly, well beyond them — there has been a large-scale shift away from government-run schools which teach predominantly in the language of the state (and offer education free of cost), and towards private English-medium schooling, which is widely viewed as being transformative of a student's prospects ( $c f$. Sancho 2015a; Mathew 2016). In Bangalore, the capital of the south Indian state of Karnataka-where I conducted the fieldwork on which this article is based — the shift to English-medium education has been particularly dramatic. According to the State Department of Education's latest report (2013), between 2006-2007 and 2012-2013, the number of private English-medium schools in Karnataka increased by 43.3 per cent (the percentage increase in English-medium schools in Bangalore is likely to have been higher). In 2012-2013, 83 per cent of the school-going population of Bangalore was studying in private schools (the vast majority of which were English-medium), and only 15.5 per cent of students were enrolled in government-run schools (which taught predominantly in the state language, Kannada). ${ }^{1}$ Until recently, scholarship on schooling in India tended to draw a dichotomy between 'English-medium schools' and 'vernacular-medium schools', with English-medium schools being discussed as attended by the elite, and vernacular-medium schools as attended by the masses. As demonstrated by the figures above, the distinction between these two categories of schools is far less stark.

The vast majority of students getting an English-medium education in Bangalore, and in India, more generally, attend private, low-cost English-medium schools, which have 
proliferated across the country over the last three decades. Do students' experiences at these schools match up to the widespread ideology of English-medium education's transformative potential? While some scholars have praised low-cost English-medium schools in India for 'democratising' access to English language skills (Jain and Dholakia 2009; Tooley 2009; Vachani and Smith 2008), others have been less optimistic, arguing that such schools are usually English-medium only in name, and so their increasing popularity—rather than enabling socio-economic mobility for large sections of the population-merely contributes to the reproduction of existing inequalities (Annamalai 2005; Mohanty, Panda, and Pal 2010). It has also been argued that low-cost English-medium schools in fact doubly disadvantage students because when instruction is offered in a language in which teachers are not proficient, students' access not just to English, but education more generally is compromised (Bhattacharya 2013; Sarangapani 2009).

However, only a handful of studies have examined 'education-in-practice' in the classrooms of low-cost English-medium schools (Bhattacharya 2013; LaDousa 2014; Smith et al 2005). Furthermore, the outcomes of study at low-cost English-medium schools have tended to be explored in terms of 'objective' indicators such as exam scores, rather than in terms of the views of the students or graduates of these schools and their families. Finally, while Indian parents' views about the importance of English for their children's lives and future prospects have been examined (Faust and Nagar 2001; Ganguly-Scrase and Scrase 2009), and how parents imagine English-medium education and vernacular-medium education has been explored (LaDousa 2014), parental expectations from low-cost Englishmedium schooling have received less attention. Given that low-cost English-medium schools account for the majority of education provision in many Indian cities, and are attended by a significant proportion of the Indian school-going population, it is important to understand the kind of teaching and learning that take place in these schools, the kind of outcomes that result, 
and how they match up to parents' and students' expectations. This article attempts to provide such an understanding, drawing on ethnographic fieldwork conducted in Bangalore.

In doing so, this article joins anthropological scholarship which has examined whether people's experiences of education match prevalent narratives of education's value. Writing about India, scholars like Jeffrey et. al. (2008) and Froerer (2012)—drawing on Bourdieu's work on education, aspiration, and inequality (1974, 1984, 2000) - have argued that education is best thought of as a 'contradictory resource' (Levinson et al. 1996, 1), as a person needs to have economic resources and social connections in order to reap its promised benefits. Thus, while education can facilitate upward social mobility for some, it also reproduces existing inequalities, apart from creating new ones. Similarly, Sancho (2015a) argues that while private English-medium education has come to play a central role in middleclass strategies of mobility in urban Kerala, in an increasingly stratified schooling sectorconsisting of government schools, aided schools, and a range of private schools, from the low-cost to the international - new inequalities are being created based on differential access. Through a focus on low-cost English-medium schools, this article investigates specifically whether the ideology of English-medium education's transformative potential squares with most people's experiences of this education in urban India. The article argues that the proliferation of low-cost English-medium schools has contributed to very real socio-economic mobility among the expanding Indian middle classes, and those who aspire to join their ranks, while simultaneously also creating new types of inequality, based on English proficiency.

In what follows, I first outline the fieldwork on which this article is based, and provide some background information about Bangalore, the city in which I conducted the fieldwork. I then move on to the core sections of the paper: I start by unpacking the reasons behind the widespread shift to English-medium schooling in Bangalore. Next, I explore how parents went about choosing a school for their children out of the numerous options in the 
expanding landscape of low-cost English-medium schools in the city. I then examine the teaching methods used in the low-cost English-medium schools at which I conducted fieldwork, and the factors which promoted the use of these methods. Finally, I discuss the outcomes of attending a low-cost English-medium school, as they were experienced by parents and graduates of these schools.

\section{Methods}

This article draws on 15 months of ethnographic fieldwork I carried out in Bangalore between 2011 and 2012, for a research project on the English language and middle-class formation in post-liberalization India. I conducted fieldwork at low-cost English-medium schools, state-run schools, commercially-run spoken English Training Centres (ETCs) targeting adults, and corporate organizations conducting English classes for their employees. I also conducted interviews with parents whose children attended low-cost English-medium schools or staterun schools. In the rest of this section, I will describe in more detail the fieldwork I conducted.

I conducted fieldwork at 12 private low-cost English-medium schools in the city. I chose schools that were in different neighborhoods of the city and charged fees ranging from Rs 300 to Rs 1000 per month (some NGOs in the city used this fee range to define low-cost English-medium schools, and in any case a large proportion of schools in the city fall in this fee range.) At each of these schools I conducted interviews with the staff and/or management, and in six of these schools I also observed classes (from classes in primary sections to classes in high school sections), attended staff meetings, and spent extended time in the schools' staff rooms. I spent approximately one week in each of these six schools.

Furthermore, for three months, I worked as a conversational English teacher myself at one of these schools, which charged fees of Rs 1000 per month. I spent three days a week at the school, and taught students from Standard 2 (age 7) to Standard 9 (age 14). In addition, I interviewed the parents of 20 of my high school students. These parents all identified as 
'middle class', although there were definite variations in their economic backgrounds, and in terms of occupation they ranged from accountants, BPO (Business Process Outsourcing) employees, and nurses to autorickshaw drivers, maids, and coolies. I also interviewed twelve autorickshaw drivers whose children attended English-medium schools within the fee range of Rs 300 to Rs 1000 per month. These drivers self-identified as middle class too. While for some, their children's school fees amounted to a part of their income with which they could afford to part, though they still felt the pinch, others could barely afford to pay these fees.

In terms of language background, the majority of these parents were Kannada speakers, but some were Tamilian, Teluguites, or Urdu speakers (though most could also speak Kannada). They varied in terms of their English proficiency. While some had a functional grasp of the language, others couldn't speak or understand it. The exposure their children received to English also varied: some were exposed to English outside of school (mainly through television, and in some cases through limited exchanges in English with parents and other family members), but others received very little such exposure. The children at the less expensive end of the low-cost English-medium school spectrum tended to have less exposure to English outside of the school than those at the more expensive end.

I also conducted interviews with the staff and management at 10 state-run schools that taught predominantly in Kannada. At one of these schools, I taught conversational English to high school students for three months (working two days a week), and conducted interviews with some of their parents. The parents of the students at these state-run schools belonged, on the whole, to a lower socio-economic background than the parents of the children I met at English-medium schools, and most did not identify as middle class. Many worked as house maids, street sweepers, or day laborers, a number lived in slums, some were single parents. Some sent a few of their children to English-medium schools (usually the sons), but couldn't afford English-medium education for all their children. In terms of language, these parents 
came from similar backgrounds to the parents of children who attended low-cost Englishmedium schools. However, the vast majority couldn't speak or understand any English.

Finally, I carried out fieldwork at ETCs, which offered spoken English courses for adults, and three corporate organizations (a multinational IT company, a multinational bank, and a private hospital), which were conducting English classes for their employees. These fieldsites gave me the chance to meet adult graduates of low-cost English-medium schools who were now in a range of occupations from engineers to BPO employees to sales staff at malls to administrative assistants at hospitals. For seven months I worked as an English language instructor at two ETCs (teaching six days a week, for three to six hours per day), and at the bank I taught an 80-hour-long "Language Proficiency Training" programme. I also conducted interviews with my students at both these fieldsites. I observed a one-month-long English language course at the hospital, and one week of English classes at the bank, and conducted interviews with both trainers and students. Some of the people I met at these fieldsites had children who were attending low-cost English-medium schools, and so I additionally interviewed them regarding their educational strategies for their children. I conducted a total of 90 interviews across all my fieldsites. When I refer to my interlocutors in this article, I am referring to the staff at the schools, the parents, the ETC students, and the employees at the corporate organizations, whom I interviewed and spent time with.

What constituted proficient or good English varied depending on whom one asked. However, all my interlocutors - even the ones who knew close to no English themselvesemphasized the importance of being able to speak English with confidence, not just read and write it. They used a handful of terms to make distinctions between the different types of Englishes they heard being spoken in the city. Most commonly, they made distinctions between 'local English,' 'normal English,' and 'hi-fi'/ 'hi-tech'/ 'professional English'. While 
the term 'local English' was usually used to refer to error-ridden English, 'normal English' referred to English that was largely correct but not stylish, and 'hi-fi English' referred to very stylish English (a 'big' vocabulary, a pan-Indian accent free of Mother Tongue Influence or 'MTI' as ETC trainers referred to it, and the confidence that came with such English).

\section{Bangalore}

Before I proceed to the core of the article, I will briefly provide some information about Bangalore, the city in which I conducted my fieldwork. A city of around nine million people, Bangalore is the capital of the southern state of Karnataka and the fifth largest city in India. Over the last 20 years, the growth and success of Bangalore's Information Technology (IT) industry has led to the city gaining iconic status as the 'Silicon Valley of India'. Furthermore, a large Information Technology Enabled Services (ITES) sector has grown around the city's IT sector. Employment in this sector includes jobs in call centres, back office operations, medical transcription, medical billing and coding etc. The success of the IT-ITES sector has also contributed to the growth of the city's private service sector more generally, and the creation of job opportunities in the fields of banking, engineering, construction and real estate, law, retail, hospitality, transportation, education, healthcare-related services, and the media.

Kannada, Karnataka's official language, belongs to the Dravidian language family and has over 55 million speakers. As a result of a number of waves of immigration from other parts of India into Bangalore, beginning as early as the $16^{\text {th }}$ century - the most recent and significant of which has been the result of Bangalore's IT-ITES-enabled boom-a number of languages are spoken in the city, apart from Kannada.

\section{The shift to English-medium schooling}

In this section, I explore the reasons behind the widespread shift to private English-medium schooling in Bangalore. I show how English-medium school attendance was seen as 
significantly improving a student's prospects, as well as enabling a family to perform levels of consumption appropriate for their class position.

In his book about language, education, and social class in India, LaDousa $(2014,134)$ argues that in spoken discourse in Varanasi, there is no 'unified hierarchical principle' that bifurcates Hindi- and English-medium schools. Even though a Hindi-medium education (and the limited English it was imagined to produce) was seen as disqualifying a person from the attractive 'middle-class' jobs available in Delhi and 'beyond', LaDousa describes how there were many employment opportunities within Varanasi—seen as being compatible with middle-class status - for which an English-medium education was not necessary. Sending one's children to a Hindi-medium school was not seen as incompatible with being middle class. Indeed some of the students who attended the Hindi-medium schools LaDousa visited were the children of doctors, engineers, and professors. By contrast, in the comments and observations of my interlocutors in Bangalore, Kannada-medium schools were always constructed as peripheral and the last resort of even the poor. This could be attributed to the fact that Bangalore had an economy very different from that of Varanasi, as well as to the fact that Kannada — despite being the official language of Karnataka—was not associated with ideas of centrality in the manner that Hindi was in Varanasi.

The staff and students at ETCs, teachers and principals at both English- and Kannadamedium schools, the parents I interviewed, employees at the corporate offices at which I conducted fieldwork - people who came from a range of socio-economic and educational backgrounds - all told me that almost nobody went to Kannada-medium schools anymore. In order to make clear to me how low the desire for English-medium education had percolated, they would tell me about the kinds of people who sent their children to English-medium schools these days — even maids, auto-rickshaw drivers, vegetable vendors and masons! People who were poor and had very little, if any, education themselves. Often, I would be 
given specific examples: 'You know this building's watchman? Even he sends his children to an English-medium school!' Or, the teachers/principal of a private English-medium school might describe to me the economic position of the school's students, and how even parents as poor as theirs viewed investing in English-medium education as important. 'Most of these children come from the slums,' the principal of Blossom School told me. 'Around 75 percent of their parents are illiterate.' Some of my interlocutors were maids, drivers, and watchmen, who were sending their children to English-medium schools, and they described an increasing number of people in their circles doing the same.

When I asked who sent their children to Kannada-medium schools, I was told that it was only the poorest of the poor, the most disadvantaged of the disadvantaged. When I asked Parvathi ${ }^{2}$ — who worked as a maid and sent her sons to an English-medium school—about who sent their children to Kannada-medium schools, her face contorted in sympathy. 'Poor things, may not have money...problems at home,' she said. 'If the husband is ok, the wife won't be. If the wife is ok, the husband won't be ok. Such problems at home. Children are neglected. ${ }^{3}$ Frequently, the characteristics of 'carelessness' and lack of knowledge and awareness were attributed to parents who sent their children to Kannada-medium schools as explanation for their educational decisions. Such parents weren't interested in their children's education, they didn't think about their children's future. On an auto-rickshaw journey that took me past a number of government schools that had an abandoned-look about them, I asked the driver who sent their children to government schools. Only people who had a pride and love for Kannada, he replied at once. 'Really?' I asked. He threw his head back and laughed heartily by way of answer.

The parents I interviewed whose children attended Kannada-medium schools were defensive, describing to me their financial situation and asking me how they could have possibly found the money for an English-medium school. When I was speaking to Kalpana 
about the English-medium school her children attended, her mother, Angamma, interrupted us: 'She [Kalpana] has only two children,' Angamma told me, in Tamil. 'That's why she can send them to English-medium. I had to educate four children! And I was earning much less than her. How could I have sent them to English-medium?'

The English-medium school experience - even that offered by a low-cost Englishmedium school — was almost unanimously regarded by my interlocutors as being significantly superior to the Kannada-medium school experience. The distinction made between these two categories of schools was based on medium of instruction, no doubt, but also-very importantly — on type of management (private or government-run) and perceived quality of education. From my interlocutors' comments in various conversations we had regarding schooling, a school that provided good quality education emerged as being one that enabled a student to acquire proficiency in English (particularly the ability to speak English), prepared a student well for his/her exams, and maintained discipline, strictly enforcing rules that dictated students' behaviour, way of dressing etc. English-medium schools were widely regarded as providing a better quality education than Kannada-medium ones, for reasons that had to do both with medium of instruction and type of management, as I will explain in what follows.

Private schools were usually English-medium, and state-run schools taught predominantly in Kannada. The categories of 'English-medium' and 'private' on the one hand, and 'Kannada-medium' and 'government' on the other hand, had come to be so closely associated with each other that people regularly used them interchangeably, as if the terms were synonyms. My interlocutors viewed English-medium/private schools as offering better quality education because they were accountable to fee-paying parents ( $c f$. Tooley 2009). At Kannada-medium/government schools, my interlocutors told me, classes were irregular, teachers taught in a perfunctory manner, unconcerned about whether students were paying attention and following the lesson, very little effort was made to enforce discipline and 
regulate students' conduct, and much of the time students were left to their own devices. ${ }^{4}$ 'In government schools, maximum what will be the punishment for the teachers if they don't teach well?' Venkatesh, a parent, asked me, a look of disgust on his face. 'Transfer. In private schools if you don't teach well, immediately they'll kick you out and appoint someone else. Whereas whatever the government school teacher teaches, he will have his job till retirement. So he doesn't care. In private schools they want more results. Otherwise the school's name will be spoilt.' Several other parents I interviewed told me that private schools were better than government schools because in private school 'you can ask' (you can question the school if you are unhappy/concerned about your child's education). Parvathi, a parent who sent her sons to an English-medium school, told me: 'English madam [teachers in English-medium schools] is always strict. [...] What she teaches, it sticks in the mind. In Kannada-medium schools, one child does like this, the other does something else. Miss will keep teaching, feeling that however much you teach, it's the same, anyway these children cannot learn. She writes on the board and goes to a meeting.'

While English-medium/private schools emerged, in my interlocutors' accounts, as places of discipline and focus, Kannada-medium/government schools emerged as places of neglect and hopelessness, not just because of teachers' lack of investment in their students' academic success but also because of the kind of students government schools were imagined to attract: children from 'careless' families, who lacked proper parental guidance and supervision, and were disinterested in their studies.

English-medium/private schools were also regarded as superior to Kannadamedium/government ones for reasons that pertained to medium of instruction. My interlocutors told me that the benefit of receiving instruction in English was significant and potentially life-altering. While government-run schools might be able to teach their students to read and write English, it was strongly felt that in order to learn how to speak English — and 
speak it with confidence and style — attending an English-medium school was necessary. Parents were convinced that their children would learn English better at an English-medium school than at a Kannada-medium one, not because they imagined that English-medium schools taught English better. Rather, English-medium schools were valued because of the exposure they offered their students to the English language, which the vast majority of these students would be unable to get otherwise. It was widely believed that the earlier a child was exposed to English, and the greater the exposure he or she received, the better he or she would learn the language. At English-medium schools, from the age of 3, students were taught all their subjects in English (or at least in a combination of English and Kannada), used text books written in English, and wrote tests in English. Furthermore, many English-medium schools in the city insisted that students speak only in English on the school premises, and even levied fines on students who were caught speaking other languages, people told me approvingly. Spending time in such an English environment, it was felt, would enable students to acquire a fluency and competence in English that was regarded as critical for their lives. In Kannada-medium schools, by contrast, the only exposure to English that students could receive was during the English language class each day. And even in this English class, my interlocutors - many of whom had studied in Kannada-medium schools themselveswere quick to mention, it was more likely than not that the teacher wouldn't use much English. It was also felt that the English teachers at Kannada-medium schools were less proficient in English than the teachers at English-medium schools. While government schools paid attention mainly to formal qualifications when recruiting teachers, I was told, private schools focused on teachers' ability to speak English.

Both parents of children who attended English-medium schools and Kannada-medium schools told me about how children who went to even low-cost English-medium schools spoke and carried themselves with a certain confidence that Kannada-medium students 
lacked, and attributed this directly to their relative comfort with English. 'Now because we don't know English, our confidence has come down,' Kalpana told me. Kalpana had attended a Tamil-medium government-aided school, but was sending her daughters, Sitara and Shalini, to an English-medium one. 'But if you look at Sitara,' Kalpana went on, 'she is not scared of anything. Wherever she goes she can speak confidently. These English-medium students become very brave and confident.'

People also spoke about the need to invest in private English-medium education in terms of the status and respect that association with this category of schools brought parents and their children ( $c f$. Faust and Nagar 2001). Sending one's children to an Englishmedium/private school, even a low-cost one, it appeared, had come to be experienced as being necessary in order to be able to demonstrate what were considered respectable levels of educational consumption. Parents continually stressed the pressure they felt to send their children to a school which was appropriate for their (the family's) 'level'. The smart uniforms children set out in every morning and returned in every afternoon, the school-bags they carried, the school buses and auto-rickshaws in which they travelled, all become important signs of a family's educational consumption. This contributed to the pressure that many parents felt to send their children to English-medium schools, even when they were barely able to afford it. A number of fathers I interviewed - after speaking to me about the evils of private schools (fees they couldn't afford, too much responsibility placed on parents etc.) would tell me that they were sending their children to private English-medium schools because of pressure from their wives. This pressure was described as being the result of their wives' 'natural' desire to want the best for their children, as well as a sort of peer pressure. 'I finally decided to put [my son] in an English-medium school, as per my wife's wishes,' Ramamurthy, who worked as a watchman, told me. 'After all, how long can you keep looking at a person weeping?' 
The markers of Kannada-medium/government school attendance, as they appeared in my interlocutors' accounts, were several: the standard blue uniform, often not properly ironed; the frequent absence of shoes (many students instead wore rubber slippers or sandals); the act of walking to one's school (children usually went to the government school in their neighbourhood, and most children walked to school). 'They dress any which way, no shoes, they go barefoot, I see all this,' Parvathi, whose children attended an English-medium school, observed. 'You just go straight on this road, there is a Kannada school. They go any which way. Books won't be there. [...] I keep seeing this all the time. When [their parents] see other children [who go to English medium], they wish, "Oh, my children too should be smart like this." "People will treat English-medium children and Kannada-medium children differently,' Mahesh, an ETC student of mine — who had himself attended a Kannada-medium school—told me. 'Kannada-medium children, they will look down [on]... think like, "Oh, he is only Kannada-medium. Useless fellow, no scope for his future."”

Benei (2005) argues that the vast majority of Marathi-speaking middle-class people in Kolhapur preferred not to send their children to English-medium schools, because they felt a deep attachment to the Marathi language — which they experienced as an important part of their Maharashtrian and even Indian identity — and viewed English as a foreign language. While my interlocutors also expressed varying levels of attachment to their mother tongues, the idea that such attachment to and pride in the mother tongue might prompt parents to send their children to a Kannada-medium school seemed ridiculous to the vast majority of them.

\section{Seeking the best English possible}

In my interlocutors' accounts, English proficiency emerged as a critical skill to possess for a number of reasons. English was needed for higher education and to get a job. For instance, more prestigious courses like medicine and engineering were offered only in English. In any case, my interlocutors spoke about how—with respect to jobs in the private sector-having 
good educational qualifications/technical skills/talent did not amount to much and might not be recognized if one were not proficient in English, and about how English proficiency was often the main skill based on which people were hired. Furthermore, an extremely wide range of jobs now required people to be able to communicate in English: it was not just software engineers and call centre workers in multinational companies who were required to be proficient in English, but also salespeople in malls and waiters in cafes (though of course the level of English proficiency expected varied). I was told that even state government jobswhich had for decades required only proficiency in Kannada—now required one to be competent in English, and it was only the low-rank government positions that were accessible to those who weren't proficient in the language. My interlocutors also experienced a number of places in the city, in which they aspired to participate, as being 'English spaces': malls, large stores, many restaurants and cafes, and private banks and hospitals. The signage at these places was often only in English, and my interlocutors explained to me that English was the main language spoken by the members of staff. Knowing English was then also experienced as necessary in order to navigate an increasing number of spaces in the city.

My interlocutors described how being proficient in English was seen as indexing modernity, sophistication, and a person's membership to a particular socio-economic background. In addition, it was strongly associated with being socially skilled, well educated, intelligent, and 'professional' ( $c f$. Kumar 1996, 59-73; Sancho 2015b). Indeed, a person's ability to speak English—and the kind of English they spoke—was experienced as shaping significantly how they were viewed and treated by others, in an increasing number of spaces and contexts in the city. Not being able to demonstrate competence in English was imagined to reveal one as uneducated, unintelligent, rural, and of low socio-economic background. Vaish argues that in India, 'English is a functional workplace language and the mother tongue shoulders the burden of identity, culture and religion' $(2005,203)$. However, as I have 
described, my interlocutors experienced their identities as closely tied up with their proficiency in English. Indeed this was an important reason why parents made substantial efforts to admit their children to a school where they would be able to learn good English.

When selecting an English-medium school for their children, the parents I interviewed took into account a number of factors like the board to which a school was affiliated (some boards were considered to be more prestigious yet more academically challenging than others), the 'reputation' of a school in terms of academic success (what were the scores of students who had studied at the school previously?), the advice of people they knew, their own observations of various schools and their students, and, of course, the fees schools charged. Very importantly, a large section of my interlocutors-ranging from parents who worked as BPO employees to parents who worked as cooks, maids and watchmenseemed to take into account the kind of English a school was viewed as being able to teach its students, in their decision-making process. In their discussions with me, parents informally categorized and ranked schools in various ways, using terms like 'fully English-medium', 'hifi', 'international' to designate the ones which were imagined to equip students with a good level of English proficiency. It was widely acknowledged that low-cost English-medium schools were unlikely to be able to impart the level of English proficiency that these more expensive schools could. Most of my interlocutors selected a school for their child, which they felt was as good as possible given their 'level' or economic position.

LaDousa (2014) writes that for most people in Varanasi, sending one's child to an English-medium school in the city, rather than a Hindi-medium one, was seen as being the way to ensure that they learnt good English. However, the more elite people in the city viewed only certain kinds of English as being valuable in the national market, and did not regard Varanasi's English-medium schools as being capable of teaching their students this kind of English. These parents sent their children to schools outside the city, in places like 
Delhi, where it was felt they would be able to learn the English they needed for future success. However, people who were educated in English-medium schools in Varanasi, LaDousa tells us, were unlikely to experience their English proficiency as 'meaningfully deficient' because they operated in a language market different from the one in which those educated in the superior English-medium schools outside Varanasi operated. LaDousa writes: 'they sense threats to someone educated in a Hindi-medium school, and tell conflicted stories about the threat, but do not sense threats to someone educated in an English-medium school such that their English might be seen as deficient' $(2014,104)$. By contrast, all of the parents with whom I spoke - regardless of the kind of school they had personally attended or sent their children to- - were very sensitive to the fact that different levels of English-medium schools produced different kinds of Englishes, and these Englishes were hierarchically ordered. Many of my interlocutors (parents, school teachers, ETC students)—who had attended Kannada-medium schools and a range of low-cost English-medium schools—could tell stories of the various points at which they had come to feel that their English was meaningfully deficient. Most commonly: when they had moved to a better-quality school or came into contact with people from such schools, when they had begun college, when they had started applying for jobs, and when they'd visited certain spaces in the city like malls, big hospitals etc. At all these points, they had encountered English that they had felt was superior to their own, or had been explicitly told that they needed to improve their English. My interlocutors at the ETCs at which I conducted fieldwork-whether they studied in Kannadamedium schools or English-medium schools—-had sought ETC courses precisely because they felt that their English was meaningfully deficient. This was perhaps why many parents—not wanting their children to suffer like them, as they often put it — felt the need to invest in the best possible English-medium school they could afford (however difficult it was for them), 
and why the differences in the kinds of English that different schools taught became significant for them.

Even those parents whose English proficiency was limited or non-existent, tried to gauge, in various ways, the kind of English different schools were able to teach their students. For some of the parents I interviewed, the main priority was that a school should actually be able to teach its students how to speak English. They told me that Kannada-medium schools and many English-medium schools simply produced students who could read and write English, but not speak it (indeed some of them said that they were products of such schools). This was not proper English, or the kind of English children needed for their futures. Others - typically those parents who were more proficient in English — tended to speak, in addition, about 'accent' and 'style' when discussing with me the kinds of Englishes different schools in the city taught, and the kind of English that they wanted their children to learn. Avinash, an ETC student of mine — who had himself studied at a low-cost English-medium school in Raichur (a city in northern Karnataka), and now worked as a software engineer in Bangalore-observed: Avinash: Now parents are very much cautious and they know that their kids need English, and they are putting them in English-medium. Simply they are not putting them in any English-medium school [They spend time trying to find a good school]. There are many English-medium schools, Kannada medium schools are gone now...almost gone. Even autodrivers are trying to put their kids in English-medium. And even they are trying to analyse and identify which school is better. They may be able to afford schools that are around Rs 10,000 or Rs 20,000 fees [per year]. In that range many schools might be there. They try to identify which school is better. Me: How will they identify? Avinash: They will ask their friends, relatives, neighbors. After admitting their kid to that school, after few years if they find it's not so good, they will shift the child to 
another school. Now parents have become very much serious...because they know that people are struggling.

Once they had admitted their children to a particular school, parents made some effort to gauge whether they were learning English properly. Those who felt concerned that their children were not picking up English well would sometimes go to the school to make inquiries. Some parents who were unhappy with their child's English acquisition moved him/her to a different school. Sandhya, who worked at an education-related NGO at which I conducted some fieldwork, told me the story of her brother's daughter: 'First, we'd put [her] in one convent [school], St Philomina's high school. After studying for three years in the school, in the fourth year she still couldn't speak English at all. [...] We felt we'd wasted four years of money [...] Then we moved her to National School.' 'Does she speak English well now?' I asked. 'Yes, she speaks well,' Sandhya smiled. 'For our level'.

\section{Teaching and learning in English-medium}

As I learnt from my fieldwork at ETCs and corporate organizations, many graduates of lowcost English-medium schools - upon moving to college, trying to apply for a job etc. — came to feel that their English was inadequate and 'meaningfully deficient', to use LaDousa's words. The staff and management at most of the low-cost English-medium schools at which I conducted fieldwork also spoke about how there was a gap between the English their students acquired at the school and the English they needed for life beyond the school.

Students' inadequate English proficiency, particularly their poor English 'communication skills' were frequently attributed by school managements and staff to students' 'background' and 'home environment'. Students didn't come from English-speaking environments, I was told, and this had a significant impact on their level of English. Teachers explained to me that there was only so much a school could do in terms of its students' English abilities, the rest depended on their background. However, schools also viewed the methods they used to 
teach — the subject of English as well as all the other subjects - as contributing to their students' inadequate communication skills. Although, of course, there were differences in the manner in which classes were conducted both within the low-cost English-medium schools at which I carried out fieldwork, and between them, there were also some striking similarities. I will begin by briefly outlining certain patterns of teaching and learning that I not only encountered in the classes I observed, but was also told about in the interviews I conducted and the conversations I had with both teachers and students at these schools. Even my ETC students who had attended low-cost English-medium schools provided accounts of how they had been taught and how they had studied that corresponded very closely with the patterns I observed during my fieldwork. These patterns of teaching and learning also corresponded with Kumar's (1998) descriptions of pedagogical authoritarianism and a 'textbook culture' in the Indian education system, and bore some similarities to the styles of teaching described by LaDousa (2014), Vaish (2008), Advani (2009), Smith et al. (2005) and Sarangapani (2002). I will then discuss the factors that promoted the use of these methods.

In most of the classes I observed, class time was typically spent on what I will call 'explanation' and 'note-giving'. Explanation of a lesson in the textbook usually involved it being read aloud by the teacher-or by various students in the class, on the instruction of the teacher-followed by the teacher either paraphrasing the lesson for the class in English or a combination of English and Kannada, or providing a translation of what the lesson meant in Kannada. While those teachers who were more proficient in English paraphrased lessons in 'simple' English, in classrooms where teachers and students possessed very limited English proficiency, Kannada was heavily relied upon. Beyond asking students to read aloud from their textbooks, teachers solicited participation from the class by asking questions of various types - to either individual students or the class as a whole - in the course of their explanation of the lesson, or after they had finished explaining it. These questions typically required 
students to recall specific bits of information which they had just been presented, or which could be found in the text of the lesson.

At the end of each lesson in the textbook were a list of questions about the lesson on which students would be tested in their tests and exams. Some of these questions were in the form of fill-in-the-blanks or multiple-choice-question exercises, while others required students to write between two- and ten-line answers. Most questions could be answered by reproducing sections of the text of the lesson. Note-giving involved either the dictation of the answers to these questions, or - in cases in which students were thought to not be proficient enough in English to be able to take dictation-the writing of these answers on the blackboard. In some of the classes I observed, the teacher herself dictated/wrote out the answers (or 'notes'), while in others a student from the class was given the teachers' notes and instructed to carry out this task. Students copied these notes into their notebooks, and studied them as preparation for tests and exams. Many students-I learnt from both teachers and students' accounts, and the test and exam papers I read-'by-hearted' (learnt by heart) their notes either partially or completely.

Apart from Mathematics, most subjects were taught, tested, and learnt in the manner described above, including English. The lessons in the English textbook were short-stories, short non-fiction pieces, poems, or excerpts from plays. English textbooks also included spoken English exercises and activities (most of which required students to read out a stilted and sometimes error-ridden script of a conversation) and grammar-related exercises. In the classes I observed, the spoken English exercises were usually skipped, and the grammar exercises were taught in a technical manner, with the aim of getting students to be able to perform well on the grammar sections of their tests and exams.

I will argue that the methods used to teach/learn that I have just described were shaped, promoted and necessitated by an interplay of various factors. One major factor was the nature 
of the examination system, together with the fact that educational success was predominantly viewed and understood in terms of success in exams. Kipnis $(2011,156)$, writing about education in China, argues:

[...] audit procedures have threatened to become the 'tail that wags the dog' of organization goals in many Western settings. In the Chinese instances it seems rather that the tail has become the dog. That is to say, auditing, or to translate more precisely, assessing and examining ( $k a o$ ) procedures explicitly become the organizing framework for the entire field they claim to assess.

In India too, it could be said that examinations were not the tail that wagged the dog, but had become the dog itself. In the case of private schools, obtaining high exam scores was a major priority of not only individual students (who needed good scores to get into college and be considered for certain jobs) and their parents, even schools were very invested in their students' exam success, given that these scores would be taken as an important marker of the school's quality. Teachers were thus under pressure - from school managements and parents - to make sure that their students performed well on their exams. ${ }^{5}$ In all subjects other than mathematics, the questions that appeared in the tests and exams that the school conducted — and even in the Standard 10 final exams, conducted by the educational board to which the school was affiliated-were some variation of the questions in the textbook, and these questions could be answered by merely reproducing sections of the textbook. As a result, in all the schools I visited, teachers felt that class time was most productively spent preparing students with the material that they needed for the next round of tests or exams. And it was possible - to a large extent - for students to pass/do well just by learning this material, and for the system to produce 'successful' results.

The teachers at the schools at which I taught would sometimes visit my English classes — in which I got the students to do role-plays and play games_-and later tell me that 
they had really liked the methods I used. It was only through activities of the kind I was conducting that students would be able to improve their communication skills, many would observe. All were quick to add that the only reason that I was able to use such methods was that I was teaching a subject that was not going to be assessed in the exams, and thus was under no pressure to finish a syllabus and ensure that students were well prepared. 'It takes so long to give them the explanation, and then to make them write the notes,' one teacher told me. 'Your methods are good, they are getting a chance to speak English...that will really help them...but if we also start doing all this, we will never complete the portions...And when they don't get good marks on the exams, parents will come and complain to principal'. The level of teachers' and students' English also significantly shaped the methods that were used to teach, and the forms that classroom activity took. The analytical category of 'safetalk' is helpful in exploring how this happened. The concept was first used by Chick (1996) to explain certain patterns of classroom activity that he observed in the KwaZulu schools he studied. These schools were forced to provide instruction in English, a language which was imperfectly understood by both teachers and students. In order to cope, teachers relied on teaching practices and types of interaction that posed minimum risk of loss of face to students, and — most importantly—to themselves. For instance, classroom activity was limited to the teacher reading from the textbook and getting the students to repeat after her, or asking questions to which students were required to provide cued choral responses. The writing that students were required to do was restricted to copying from the blackboard. Though such routines did not facilitate any learning, they served to 'construct the fiction that classroom activities were maintained' and provide a 'sense of purpose and accomplishment' (Hornberger and Chick 2001, 42). They thus served a social function, at the cost of an academic one. Following Chick, many others have drawn on and developed the construct of safetalk in discussions of classroom activity in postcolonial settings. Arthur (1996), writing about 
schools in Botswana, likens the classes he observed to a play that was being staged - in which the teacher was not just an actor (like the students), but also a director, and a prompt - in order to convey the safe, scripted nature of the teacher's speech and of classroom interaction. LaDousa (2014) illustrates how the classes he observed in Varanasi's English-medium schools, and the English classes he observed at its Hindi-medium ones, all exhibited features of safetalk in different forms. In these classes, teachers minimized interaction in English by providing limited elaboration on the lessons they taught, restricting students' participation to repetition and cued chorusing, and making use of Hindi.

The English of the teachers I met at low-cost English-medium schools varied. There was some correlation between the fee level of a school and the English proficiency of its teachers. While teachers at the more expensive end of the low-cost English-medium school spectrum spoke relatively fluent English (though many made grammatical errors), teachers at the cheapest English-medium schools I visited struggled to speak in the language. Many of the teachers I got to know during my fieldwork expressed feelings of anxiety, shame, insecurity, and inadequacy about their level of English and the effect it had on their ability to teach. They explicitly spoke to me about various strategies they employed in order to carry out the work of teaching the lessons in the syllabus in a manner that was as non-threatening as possible, and accommodated both their own lack of proficiency in English and that of their students.

The ability of many of the teachers I met to read and write English far exceeded their ability to speak and understand it. Though they could manage to read from the textbook, they found it daunting or impossible to discuss a lesson in English with their students. It thus stood to reason that in almost all the classes I observed, teachers spent most of the time reading aloud from the textbook and dictating or writing 'notes' (which could be prepared or secured in advance) on the blackboard. Some teachers, in schools which were strict about only English being used in the classroom, told me that they 'by-hearted' English explanations to 
lessons which they then recited for their students. Others relied on Kannada for all explaining or paraphrased the text of the lesson in simple English, sticking very closely to the original text, in lieu of discussing it with the students. When teachers didn't properly understand or didn't feel confident about teaching certain sections of a lesson, or exercises at the end of a lesson, these sections were sometimes simply ignored. Teachers also delimited students' involvement in the proceedings in the classroom: students' participation was restricted to taking down notes, individual and group reading from the textbook, and providing brief responses to teacher's questions about specific material they had been presented. Engaging students in this manner could give the illusion that the lesson was proceeding well, while accommodating both the students' and teachers' level of English proficiency.

The Kannada classes/Kannada-medium classes which I observed - though they were also primarily concerned with transmitting to students the material on which they would be tested in exams - were markedly different from the English-medium ones. Here, the teachers elaborated on the lesson they were teaching with confidence and ease, often engaging students in lively discussion on the topic. The fact that both teachers and students were proficient and comfortable in Kannada had a major impact on the atmosphere of and activity in the class.

\section{Outcomes}

It could be argued that the methods that schools used to teach — and the factors which necessitated these methods-led to students failing to acquire a proper grasp of all the subjects they were being taught, not just English ( $c f$. Pratham 2006). From the time I spent in various classrooms, it appeared that this might indeed be true, though an engagement with such an argument is beyond the scope of this article. However, what is relevant to this article is that while the scores students obtained in science and social studies exam papers, for instance, were to some extent taken as indicative of their grasp of the subject-in higher 
education and job markets - there were no scores or certificates that could pass for proficiency in English.

Nevertheless, my interlocutors - the staff of low-cost English-medium and Kannadamedium schools, parents who sent their children to both these categories of schools, and graduates of these schools - felt that relative to students who attended Kannada-medium schools, those who attended English-medium schools, even low-cost ones, learnt better English and had greater confidence (which was always discussed as being linked to better English proficiency). This was something that I observed too. Although the methods used in the low-cost English-medium schools at which I conducted fieldwork were problematic, shaped as they were by both an examination-centric education system and teachers' lack of proficiency and comfort in English, students still received more exposure to the English language than they would have in a Kannada-medium school. This resulted in a greater familiarity and comfort with the language. Schools at the more expensive end of the low-cost English-medium school spectrum, by and large, afforded their students exposure to more English, as well as more grammatically-accurate English than schools at the lower end of this spectrum. Again, this was reflected in the English the students of these schools acquired.

Although speaking 'hi-fi' English was imagined to improve significantly one's prospects, parents and teachers with whom I spoke stressed that even speaking some English - the kind you could learn at many low-cost English-medium schools in the city-brought benefits. One parent, who worked as an auto-rickshaw driver - in a conversation about the English-medium school his son attended - told me the difference between the kind of English his son, who attended a low-cost English-medium school, spoke and the kind of English a Kannadamedium student spoke, could mean working as a call-center agent, instead of a driver at a call-center. The principal of Blossom school, another low-cost English-medium school, told me that the students at her school were unlikely to speak English as fluently as the students at 
the bigger schools in the city (her children went to one such school), but even the English students learnt at her school could greatly benefit them. With this English, she explained, at least they could become salespersons in a mall, rather than a cleaner or someone working in the stock room of the same mall.

Most of my interlocutors could illustrate for me, through the stories of people they knew, or their own example, how even the English one could learn at a low-cost Englishmedium school could set one on a different economic trajectory from one's Kannada-medium peers. Angamma — who worked as a maid—described to me how she and her husband had struggled to educate their four children, all of whom were in their 20 s at the time that I met her. Their oldest daughter, who suffered from polio, had attended a low-cost English-medium school on a scholarship for disabled children offered by the school. They had put their next three children in government-aided schools that taught in Tamil and Kannada, unable to pay English-medium school fees without the help of a scholarship. She said that the schooling each of her children had received had shaped their respective career paths, and she felt very guilty for not having been able to give all of them a good education. Her oldest daughter, who had attended the English-medium school, now worked in a BPO doing a data-entry-related job. She was a Team Leader, Angamma told me proudly, and the salary she earned helped the family a lot. Her other two daughters had got married after finishing their pre-university degrees. The youngest daughter didn't work, but the second daughter-after separating from her husband — now worked as a maid. Her son had struggled to get a job for a long time, and now worked in a junior role in a courier company. Angamma told me:

Both the younger ones fight with me, saying, 'Why did you put us in Kannadamedium? My life is gone now because you put me in Kannada-medium.' My son feels, [...] 'If I had gone to English-medium, I could have got a good job and had a good 
life'. If you don't learn English-if you studied in Tamil-medium or Kannada-

medium-you just won't get a job. [...] Even a government job you can't get.

Similarly, Lakshmi, another parent I interviewed who worked as a maid, told me that her children - whom she had through great effort managed to educate in a low-cost Englishmedium school—now worked as accountants, and had travelled by plane on work. Her sister's son, who had attended a Kannada-medium school, worked as a mechanic.

Many of my ETC students who were Kannada-medium school graduates told me that their lack of exposure to English had shaped their higher education and career choices negatively. For example, some had decided against applying for a pre-university program in Science — despite believing that this program offered the best career prospects - feeling that enrolling on a course that was difficult to begin with (Science courses were frequently considered to be more difficult than Commerce and Arts courses), and was furthermore taught in English, would be too much to handle. Several of these students told me that they had avoided applying for jobs in multinational companies, although they felt that these jobs would offer them the best career growth, because they worried about how they would manage in the English environment of such companies.

\section{Conclusions}

Vaish, drawing on her fieldwork in Delhi, describes how government schools in the city are starting to teach English as a subject in primary school, and to even offer English-medium education, in order to cope with rapidly falling student numbers. Vaish views this as 'market driven language-in-education planning' $(2005,189)$ and argues that there is a 'bottom-up reform taking place in India's language in education policy' $(2008,7)$. She observes that with their increased efforts to cater to the rising demand for English language instruction, government schools might even give private schools a run for their money. Like in Delhi, state-run schools in Karnataka have been making concerted efforts to teach more English, and 
improve the English language instruction they offer. In 2007, the government advanced the introduction of English language classes in government schools from upper-primary school (Standard 5/age 10) to primary school (Standard 1/age 6). The primary school English textbooks were created with the objective of getting students to learn English in an organic manner: the focus was on conversational English, which was to be taught through activities. Most government schools in the state also have an English-medium section at the high school level. Nevertheless, these schools continue to witness falling student numbers. In Bangalore, at least, the real bottom-up reform taking place with respect to the teaching and learning of English at the school level is through the rapid growth of low-cost English-medium schools. Through a focus on these private low-cost English-medium schools in Bangalore, in this article I have examined whether the widely-prevalent ideology in India of Englishmedium education's transformative potential squares with most people's experiences of this education in urban India. I have illustrated how low-cost English-medium schools don't usually offer access to what my interlocutors regarded as being 'hi fi' or fancy English, the kind of English that the students at the city's more elite English-medium schools spoke. The adults I met at spoken English Training Centers, many of whom were graduates of low-cost English-medium schools, all regarded their English as deficient and some even felt their lack of proficiency in English was severely impeding their lives. The proliferation of low-cost English-medium schools has contributed to the shame that many adults feel about not being proficient in English, and the expectation that English should be learnt in childhood. Prior to this, only a relatively elite minority attended the then small percentage of English-medium schools in the city. Most studied at Kannada-medium schools, learning English as a subject, and regarded being able to read and write English, and speak some functional English, as an acceptable level of proficiency in the language. With greater numbers of people acquiring some proficiency in English, however, matters of accent, style etc.—which were only of 
concern to a minority, in the past - have become very important to a large section of the population. In this sense then, the rising popularity of low-cost English-medium schools has contributed to not just the reproduction of existing inequalities but also the creation of new ones.

Nevertheless, I have also shown how these schools, to some extent, met parents' very realistic expectations of them. Apart from the prestige associated with an English-medium education (and the stigma associated with a Kannada-medium one), parents' preference for private English-medium schools stemmed from the belief that these schools, even the lowcost ones, offered a superior education to state-run, Kannada-medium schools. For most parents, a superior education was defined in terms of exam scores and English proficiency. In keeping with what parents told me, I found that — compared to the state-run Kannada-medium schools I visited — at the English-medium ones, greater efforts were made to ensure that students performed well in their exams, and greater exposure to English meant that students acquired a greater proficiency in and comfort with the language than their Kannada-medium school counterparts. And while better exam scores are not, of course, indicative of better learning, and the kind of English students learnt was limited and imperfect, these scores and this English still positively impacted their education and employment prospects; not just in terms of getting admission into competitive courses (the most prestigious programs of higher education are available only in English, and have high 'cut offs' or the marks above which students must score to be able to enroll on them) and getting better paying jobs, but also in terms of their confidence about their capabilities.

Through this article I hope to have also illustrated how the outcomes of private lowcost English-medium schooling — or any type of schooling — cannot be evaluated merely through assessing pedagogical practices or examining test scores. Rather, a meaningful 
evaluation of education outcomes requires understanding students' and their parents' experiences of an education system and its impact on their lives.

${ }^{1}$ All government schools in the city offer instruction until Standard 8 (age 13) in Kannada (or one of the eight 'mother tongues' that the State recognises as belonging to its major linguistic minorities). In high school (Standards 8 to 10), students can opt to continue studying in Kannada, or switch to receiving instruction in English. However, the English-medium track at government schools was held in very low regard by most of my interlocutors, many of whom dismissed it as being no better than Kannada-medium.

${ }^{2}$ In order to protect my interlocutors' anonymity, I have used pseudonyms.

${ }^{3}$ When I present excerpts from conversations or interviews, text that appears in italics was spoken in Kannada (unless otherwise specified), and words that don't appear in italics were spoken in English.

${ }^{4}$ It is beyond the scope of this article to examine the significant structural constraints that impacted the running of government schools.

${ }^{5}$ In state-run schools as well, students and parents viewed obtaining high exam scores as the mark of educational success, and schools faced some pressure to demonstrate high pass percentages (though they were arguably less invested in their students' success than private schools).

\section{References}

Advani, Shalini. 2009. Schooling the National Imagination: Education, English, and the Indian Modern. New Delhi: Oxford University Press.

Arthur, Jo. 1996. "Code Switching and Collusion: Classroom Interaction in Botswana Primary Schools." Linguistics and Education 8(1): 17-33. 
Bénéî, Véronique. 2005. “Of Languages, Passions and Interests: Education, Regionalism and Globalization in Maharashtra, 1800-2000.” In Globalizing India : Perspectives from below, edited by Jackie Assayag and C. J. Fuller, 141-162. London: Anthem Press.

Bhattacharya, Usree. 2013. "Mediating Inequalities: Exploring English-Medium Instruction in a Suburban IndianVillage School.” Current Issues in Language Planning 14(1): 164-184.

Bourdieu, Pierre. 1974. "The School as a Conservative Force: Scholastic and Cultural Inequalities.” In Contemporary Research in the Sociology of Education, edited by John Eggleston, 32-46. London: Harper and Row Publishers.

1984. Distinction: A Social Critique of the Judgement of Taste. Cambridge, MA:

Harvard University Press. Cambridge: Polity Press. 2000. Pascalian Meditations. Cambridge: Polity Press.

Chick, J. Keith.1996. "Safe-Talk Collusion in Apartheid Education." In Society and the Language Classroom, edited by Hywel Coleman, 21-39. Cambridge Language Teaching Library. Cambridge: Cambridge University Press.

Department of Education. 2013. Education in Karnataka State: A State-Level and DistrictWise Analytical Report. Bangalore: State Project Director, SSA.

Faust, David, and Richa Nagar. 2001. "Politics of Development in Postcolonial India: English-Medium Education and Social Fracturing." Economic and Political Weekly 36(30): $2878-2883$.

Froerer, Peggy. 2012. 'Learning, Livelihoods, and Social Mobility: Valuing Girls' Education in Central India: Valuing Girls' Education in India." Anthropology \& Education Quarterly 43(4): 344-357.

Ganguly-Scrase, Ruchira, and Timothy J. Scrase. 2009. Globalisation and the Middle Classes in India the Social and Cultural Impact of Neoliberal Reforms. Routledge Contemporary South Asia Series, 17. London [u.a.]: Routledge. 
Hornberger, Nancy, and Keith J. Chick. 2001. “Co-Constructing School Safetime: Safetalk Practices in Peruvian and South African Classrooms." In Voices of Authority: Education and Linguistic Difference, edited by Monica Heller and Marilyn Martin-Jones, 31-55. Westport, Conn: Ablex.

Jain, Pankaj, and Ravindra H Dholakia. 2009. "Feasibility of Implementation of Right to Education Act.” Economic \& Political Weekly 44(25): 38-43.

Jeffrey, Jeffrey, Craig, Patricia Jeffery, and Roger Jeffery. 2008. Degrees without Freedom? Education, Masculinities, and Unemployment in North India. Stanford: Stanford Univ. Press. Kipnis, Andrew B. 2011. Governing Educational Desire: Culture, Politics, and Schooling in China. Chicago: University of Chicago Press.

Kumar, Krishna. 1996. Learning from Conflict. Tracts for the Times. New Delhi: Orient Longman.

1988. “Origins of India's 'Textbook Culture'.” Comparative Education

Review 32 (4): 452.

LaDousa, Chaise. 2014. Hindi Is Our Ground, English Is Our Sky: Education, Language, and Social Class in Contemporary India. New York: Berghahn Books.

Levinson, Bradley A., Douglas E. Foley, and Dorothy C. Holland, eds. 1996. The Cultural Production of the Educated Person: Critical Ethnographies of Schooling and Local Practice. SUNY Series, Power, Social Identity, and Education. Albany, NY: State Univ. of NY Press. Mathew, Leya. 2016. Aspiring India: The Politics of Mothering, Education Reforms, and English. PhD Dissertation, University of Pennsylvania.

McGuire, Meredith Lindsay. 2011. "'How to Sit, How to Stand': Bodily Practice and the New Urban Middle Class." In A Companion to the Anthropology of India, edited by Isabelle Clark-Decès, 115-36. Oxford, UK: Wiley-Blackwell. 
Mohanty, A. K., M. Panda, and R. Pal. 2010. "Language Policy in Education and Classroom Practices in India. Is the Teacher a Cog in the Policy Wheel?" In Negotiating Language Policies in Schools: Educators as Policymakers, edited by K. Menken and O. Garcia, 211231. New York, NY: Routledge.

Pratham 2006. Report on School Survey. www.pratham.org, accessed January 10, 2008. Sancho, David. 2015a. Youth, Class and Education in Urban India: The year that can break or make you. London: Routledge.

2015b. "Ego, Balance, and Sophistication: experiences of schooling as self-making strategies in middle-class Kochi." Contributions to Indian Sociology 49 (1): 26-51

Sarangapani, Padma M. 2009. "Quality, Feasibility and Desirability of Low Cost Private Schooling." Economic \& Political Weekly 44(43): 67-69.

Smith, Fay, Frank Hardman, and James Tooley. 2005. "Classroom Interaction in Private Schools Serving Low-Income Families in Hyderabad, India.” International Education Journal 6(5): 607-618.

Tooley, James. 2009. The Beautiful Tree : A Personal Journey into How the World's Poorest People Are Educating Themselves. Washington, DC: Cato Institute.

Vachani, Sushil, and Craig N. Smith. 2008. "Socially Responsible Distribution Strategy for Reaching the Bottom of the Pyramid." California Management Review 50(2).

Vaish, Viniti. 2005. “A Peripherist View of English as a Language of Decolonization in PostColonial India.” Language Policy 4: 187-206. 2008. Biliteracy and Globalization: English Language Education in India. Bilingual Education and Bilingualism, 67. Clevedon, UK; Buffalo, NY: Multilingual Matters Ltd. 